Journal of Educational Technology

\& Online Learning

Volume 3 | Issue 1 | 2020

http://dergipark.gov.tr/jetol

\title{
Design Thinking Applications in Teaching Programming to Gifted Students
}

\author{
Yunus Emre Avcu \\ Kemal Oğuz Er ${ }^{b}$ \\ a yunus1099@hotmail.com; Şehit Prof. Dr. İlhan Varank Science and Art Center, Balıkesir, Turkey; ORCID: 0000-0001-8286-0837 \\ b keoguzer@gmail.com, Balıkesir University, Balıkesir, Turkey; ORCID: 0000-0001-6098-2067
}

Doi: $10.31681 /$ jetol.671621

Suggested citation: Avcu, Y.E. \&Er, K.E. (2020). Design Thinking Applications in Teaching Programming to Gifted Students. Journal of Educational Technology \& Online Learning, 3(1), 1-30.

\begin{tabular}{l} 
Article Info \\
\hline Received : 19.11 .2019 \\
Revised : 08.12 .2019 \\
Accepted: 28.12 .2019
\end{tabular}

Research Article

\begin{abstract}
The study aimed to present suggestions for how a design thinking (DT) approach can be applied in the processes of teaching programming to gifted students and to reveal its effects on the teaching process. The case study method was used. 5 different DT tasks were defined to create solutions for an unstructured problem by using programming tools and DT processes. DT activities were applied to 25 gifted students (13 girls, 12 boys) at the Science and Art Center (BILSEM) in the city center through the summer term. Data were collected through interviews, observation forms, and the DT Rubric which was developed by the researchers. The findings showed that gifted students improved their DT skills to a certain level, learned the academic content, enjoyed the process itself, and experienced some problems working in teams. At the end of the teaching process, the students emphasized that a good designer should be a respectful person who can work well within a team. Additionally, according to the students' views, different programming tools and environments namely Scratch, Arduino IDE and Lego Mindstorms EV3 can be used in the prototyping phase of the DT processes. Updating DT tasks to include DT mindsets and taking into account the leadership qualities of gifted students during the implementation process may be suggested.
\end{abstract}

Keywords: design thinking, differentiation, gifted student, programming, activity design.

\section{INTRODUCTION}

Gifted students are those who perform at a higher level than their peers in at least one of the following areas: academic areas such as general cognitive skills, mathematics, and science; psychomotor skill areas; creativity; leadership; and/or visual or performance-based art (Clark, 2015; Marland Report, 1972; Ministry of National Education [MoNE], 2018; National Association for Gifted Children, 2019). According to Renzulli (1978), there are three sets of features that define gifted individuals, namely general and special talent, motivation (devotion to the task), and creativity. It is an obligation rather than a responsibility to provide this elite group of people who perform or have the potential to perform better than their peers with education services that they need and will be able to develop their talents in (Öngöz \& Sözel, 2018). 
Strategies of grouping, acceleration, and enrichment are used in gifted student education. Gifted students have the chance to work with students who possess similar characteristics to them by applications of grouping (Kanl1, 2008). The leading role in the education of gifted students in Turkey belongs to the Science and Art Centers (BİLSEM) and their grouping samples (Ataman, 2004). The scope of acceleration activities includes practices such as, class skipping, early school entry, participation in upper classes in a specific area or areas, and narrowing the curriculum (Gür, 2017; VanTassel-Baska \& Brown, 2000). The range of educational programs will be extended for enrichment purposes and students will be given the opportunity to focus on specialized topics and activities (Sak, 2014). Some examples of enrichment are a teacher inviting a person who is a specialist in a certain area to class in order to provide students with in-depth information, or a teacher giving research articles to students which are not a part of the current curriculum (Şahin, 2015a).

The concept of differentiation is used as an umbrella concept which covers all grouping, acceleration and enrichment strategies in the education of gifted individuals. Differentiation is a learning experience where distinct ways to explore the curriculum is used to enable students to understand the material, the teaching process and activities are coordinated in a way that allows students to make substantive learning and construct the knowledge, and choices are presented to students to allow them to show what they have learned in different ways (Tomlinson, 1995). In other words, to meet the learning needs of students who have different learning skills, interests, and readiness levels, differentiation can be applied to an education program's content, process, environment and product dimensions (Tortop, 2015). Taking into account the students' interests, learning styles and prior knowledge, the content can be differentiated. The learning environment can be differentiated in terms of material, time and space. The process dimension is influenced by the paths and methods students use in thinking and using information while participating in the learning process. Differentiation can be realized in the process dimension in terms of strategy, system, methodology, high-level thought, research, self-expression, and self-regulation skills. The product can be differentiated according to criteria such as depth, originality, unusualness, innovation, and is related to the real world (Şahin, 2015b, 2018a, 2018b).

Gifted education researchers have been working on creating models regarding the differentiation of content, environment, process and product dimensions such as "Future Problem Solving” (Treffinger, Jackson \& Jensen, 1996), “Creative Problem Solving” (Maker 
\& Schiever, 2005), "Thinking Actively in a Social Context" (Wallace, Cave, \& Berry, 2009), "Problem Based Learning" and "DISCOVER" (Maker \& Pease, 2008) for many years. By applying these models, it is aimed that gifted students will find creative solutions to unstructured problems in a social context that is close to them, and they will develop high- level thinking and metacognitive skills (Alhusaini, 2018). Design thinking is one of the models that serve to the aforementioned targets.

Design thinking is a human-centered approach that aims to find creative and innovative solutions to various social and commercial problems by using design tools and mindsets (Kelley \& Kelley, 2013, Lor, 2016). During the process of design thinking, learners work on targets that are not clearly defined and unstructured problems that have no solutions stated yet (Jonassen, 2000). The effectiveness in bringing 21st-century skills and characteristics to students creates the educational value of design problems (Koh, Chai, Wong \& Hong, 2015). The design thinking process relies on the principles of empathizing in order to understand user needs, defining the needs, making trials, prototyping, receiving feedback from users, redesigning the process (Darbellay, Moody \& Lubart, 2017) and expressing yourself through creative ways besides using words and symbols (Brown \& Wyat, 2010). Since there is no common description of design thinking in literature, there is no single way to follow the design thinking process. Institutions such as Stanford University Hasso Plattner Design School, IDEO and Design Council have developed many design process models. In all models; collecting information in order to understand the problem, using creative thinking skills in the process and being experiential during the process were always highlighted (Chesson, 2017). "D.school" describes the design thinking process phases as empathizing, defining, brainstorming (ideate), prototyping, and testing, respectively (Bootcamp Bootleg D.School, 2011). The design thinking process is a iterative process, and phases can be repeated one after the other if needed (Lor, 2016). In Figure 1, the stages of the design thinking process and their relations with each other are shared. 


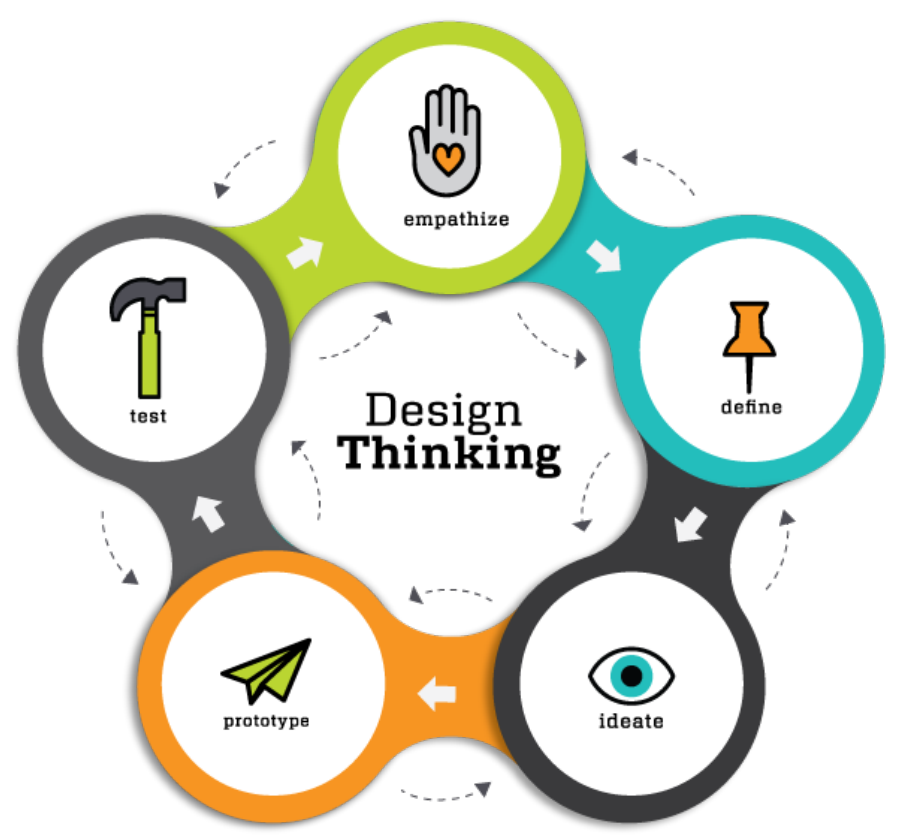

Figure 1. Design Thinking Process

Source: Ideate High Academy (2019)

The design thinking process starts with empathizing with the user. Insights of what people feel and what people think will be developed through empathy (Carroll, 2015). In order to develop insights, students observe how people behave, and how they interact with other people and the environment. Also, they can record projections regarding the answers to questions asked. This way, empathy will be established with the user (Carroll et al., 2010). When students empathize, they are not limited by their own experiences. On the contrary, they can develop new ideas and products through internalizing others' experiences (Root-Bernstein \& Root-Bernstein, 1999).

The second phase of design thinking is defining the need. In this phase, action-based problem statements will be stated after analyzing and synthesizing the data obtained during the empathy phase. Problem situations are expressed as Point of View (POV) statements which are formed by combining "User + User's Need + Insight" (Carroll et al., 2010). The problem defining phase supports creative thinking skills in the context of evaluating a situation or problem from different angles, redefining present models and enabling the production of new information by developing multiple points of view (Henriksen, Richardson \& Metha, 2017).

Brainstorming is a phase aimed at producing many ideas in various categories devoted to finding a solution for the defined problem. Students can participate in brainstorming processes 
in different groups or individually (Painter, 2018). In the Prototyping phase, a solid product is put together by taking action on the new ideas that were developed in the brainstorming phase. Any kind of thing that has a physical component such as an object, role-play activity, an interface, a visual scenario draft inherits the feature of being a prototype (Bootcamp Bootleg D.School, 2011; Carroll, 2015, Odabaş1, Dursun, Ersöz \& Kılınç, 2018). In the testing phase, which is the final stage of the design thinking process, the user is able to experience the developed prototype and give feedback to the designers. Solutions developed according to user feedback are evaluated and will be improved accordingly (Carroll, 2015). Additionally in this phase, gathering more information about the user and the improvement of POV statements after testing can be realized (Bootcamp Bootleg D.School, 2011). All the actions executed by the designer or the designing team in the design thinking processes are supported by the individual's attitude and mindsets. These processes are effective on the qualification of design thinking (Carroll, 2015; Chesson, 2017; Lor, 2016). In literature, design thinking mindsets are stated as follows; people-oriented, action-oriented, metacognitive awareness, multidisciplinary understanding of cooperation, open-mindedness, tolerance to uncertainty, teamwork, risktaking, learning-oriented, learning from mistakes/experiences, and creative self-confidence (Dosi, Rosati \& Vignoli, 2018).

In literature, design thinking is generally considered to be a teaching method and skill set, and it has been proven that the design process has positive effects on students' academic learning, cognitive, affective and social skills. Students who experience the design thinking process have the opportunity to learn about the specialties of the designers, academic content, design process, teaching-mentoring knowledge and can improve their academic success. At the end of the design thinking process, learners develop creative thinking, critical thinking, problem- solving, design thinking, meaningful learning, and metacognitive skills. In the design thinking process, students have the opportunity to progress their affective skills such as empathy, creative selfconfidence, risk-taking, assertiveness, self-sufficiency of knowledge generation, curiosity, being human-oriented and setting a career goal. Furthermore, social skills like working in cooperation, self-expression and having social interaction of learners can be improved during the design thinking process (Aflatoony, Wakkary \& Neustaedter; 2018; Bouchard, 2013; Carroll et al., 2010; Carroll, 2015; Duman \& Kayal1, 2017; Henriksen et al., 2017; Koh et al., 2015; Kwek, 2011; Noel \& Liub, 2017; Scheer, Noweski \& Meinel, 2011; Rauth, Köppen, Jobst \& Meinel, 2010). 
Design thinking can be applied in different contexts such as mathematics (Painter, 2018), graphic design (Duman \& Kayal1, 2017), social sciences (Koh et al., 2015), STEM education (Carroll, 2014) and teacher education (Carroll, 2014; 2015; Odabaş1 et al., 2018). One of those contexts is computer science education which aims at revealing the designer, developer and active participant characteristics of learners and which is addressed with works of developing solid products and software developing (Kert, 2018). During software development (in other words, the programming process), students understand the nature of unstructured problems by cooperative work, empathize, define problems, and establish, develop, and improve their program to find new, appropriate and useful solutions (Romero, Lepage \& Lille, 2017).

Programming has been thought to the gifted students of primary, secondary and high schools in the Information Technologies and Software lesson at BILSEM. In this scope, framework programs and activity books are prepared to be included the programming skills and served as a guide to the teachers who work at BILLSEM (MoNE, 2017). BİLSEM Information Technologies and Software Lesson Framework Program can be criticized for not having any differentiation strategy, and for designing activities as technology-oriented rather than pedagogical. Because technology-oriented learning-teaching processes that lack pedagogical aspects lead to inefficiency during programming education (Kert, 2018). It can be stated as a deficiency not to execute example activities in the teaching programs that are designed for the gifted students who are studying in groups by formal education (MoNE, 2019). Example activities designed for gifted students are a necessity for the BILLSEMs that are in the phase of restructuring (Ayverdi, 2018). Building and sharing activities with teachers, that utilize differentiation strategies for gifted students, eliminate pedagogical deficits, focus on accomplishments and provide meaningful learning experiences are incredibly important. In addition, designed activities should be evaluated by empirical researches (Plucker \& Callahan, 2014)

In the scope of this study, design thinking is discussed as a differentiated teaching method and skillset and applied during programming education processes for gifted students. The aim of the study is to present how a design thinking approach can be applied in programming education and to reveal its effects on the teaching process. 


\section{METHODOLOGY}

\section{Research Design}

The study examines how design thinking is applied during programming education processes for gifted students. As in-depth examination of the DT experiences of the gifted students is intended, case study, which is one of the qualitative research methods, was used. A case study is an in-depth description and analysis of a bounded system. A bounded system can be single person who is a case example of some phenomenon, a program, a group, an institution, a community, or a specific policy (Merriam, 2014).

\section{Participants}

Activities included 25 gifted students who studied at Science and Art Center (BILSEM) in the city Centre for one summer period. The study group consisted of 13 male and 12 female students. At the time of the study, 8 of the students were in 5 th grade, 7 of them were in 6 th grade, 3 of them were in 7 th grade and 7 of them were in 8 th grade.

\section{Data Collecting Tools}

Design thinking worksheets (Empathy Map, POV statements, User Feedbacks), note sheets used in the brainstorming process and prototypes developed during the DT process were examined with DT Rubric (Annex-4) developed by the researchers. The steps proposed by Andrade (2000) and Mertler (2001) of DT Rubric were used. Firstly, 5 criteria were identified as performance criteria, evaluating each step of the design thinking process (empathy, defining, and brainstorming, developing prototypes, testing). Secondly, it was decided the type of DT rubric as to be "analytical rubric". To determine whether the students gained the DT skills while performing the DT tasks, not only the products they developed, affected this decisionmaking process. Afterwards, performance levels were determined and level definitions were cleared. Performance levels were determined from the weakest to the most competent by scoring the lowest level of performance as 1 and the highest level of performance as 4 . After collecting the reviews of 8 gifted students, 1 teacher and 2 experts working on DT field, rubric was finalized. During the implementation of activities process, use of design thinking skills by gifted students is examined by DT Observation Form (Annex-5). The observation form was developed by researchers using the resources on the online platform " $\mathrm{d}$ school K12 Lab". Semistructured interviews were conducted with gifted students before and after the implementation 
of the activities. One student from each grade level (5th, 6th, 7th and 8th grades) participated in the interviews. In the interviews; questions such as how are they going to structure a design project, what kinds of tools they will use for prototyping, what they think about possible problems may be encountered during design process and what they think about the personality traits that a member of design team should inherit are directed to students.

\section{Design of DT Activities}

The activities in this study were designed to be used in information technology and software course for gifted students. There were five study units which covered block-based, text-based, physical and mobile programming, and at the end of each study unit, students were asked to develop unique projects according to the programming environment covered in each module. Prior to the project development process, the students received technical training regarding design thinking, block-based, text-based, physical, and mobile programming. The achievements of the activities are as follows:

1. Develop an original project in a block-based programming environment using design thinking process.

2. Develop an original project in a text-based programming environment by using design thinking process.

3. Develop original projects in a text-based physical programming environment using design thinking process.

4. Develop original projects in block-based physical programming environment by using design thinking process.

5. Develop an original project in mobile programming environment by using design thinking process.

For each achievement, "Design Thinking (DT) Tasks" were also determined which aimed to attract students' curiosity, increase participation in activities, and providing opportunities to demonstrate information processing skills also related with daily life as well. These tasks are stated as follows respectively; "redesigning the experience of playing computer games", "redesigning the healthy eating experience", "redesigning the experience of water use", "redesigning the experience of living safely" and "redesigning the learning experience in science and technology lesson". In all DT tasks; DT digital presentation, Empathy Map 
Template (Annex-1), Point of View (POV) Template (Annex-2), User Feedback Template (Annex-3), Online Stopwatch Web 2.0 Tool, A4 papers, sticky note papers, color pencils and Ideate Cards were used. As for programming environments and physical programming tools; Scratch Block Based Programming Environment, Python Text Based Programming Environment, Ardunio Uno Ultimate Set and Arduino IDLE Text Based Physical Programming Environment, Lego Mindstorm EV3 Education Kits and Add-on Kits, Legomindstorms Education EV3 Teacher Edition Block Based Robot Programming Environment and App Inventor 2 Mobile Programming Environment were used.

\section{Application Process}

Each of the activities lasted six lesson hours and was administered to gifted students for one day at Science and Art Center (BILLSEM). Prior to the exercise, the Design Thinking process was reminded to the students by using a digital Design Thinking Presentation. After that, students were divided into 5 groups of 5 people. Students were given their DT task, Empathy Map, Point of View and User Feedback templates and other tools related to DT task. Students were required to name their group and hold a small discussion about the DT task. During the activities process, phases of the DT process were followed.

\section{Execution Phase- Empathy}

Students are told that their group is a "design team" and will work on the DT task. A volunteer in the design team is selected as "user". The other four people are called "designers". Designers will have an interview with the user to empathize. The task assignment is done by the designer students for the interview. Students take on the duties of 1) the main interviewer 2) the person asking continuity questions (such as "For what?" and "Why?") 3) note taker and 4) time keeper. Students are given time to prepare the interview questions (10 minutes) and to conduct the interview (25 minutes). To monitor timing "Online Stopwatch Web 2.0 Tool” is used and projected onto a screen visible to students. Students are expected to complete the empathy map within fifteen minutes at the end of the interviews. At the end of this process, one spokesperson from the groups is asked to briefly summarize the empathy map to the whole class, and revisions are given to the groups about their inferences on their empathy map. If needed, students make revisions on their empathy maps. An example interview questions prepared by students for the first DT task during the phase of empathy is shown in Figure 2, and the empathy map is shown in Figure 3. 
When Figure 2 is examined, it is seen that students try to ask open-ended questions which may reveal user experiences, but they do not use continuity questions as much. When the empathy map showed in Figure 3 is examined, it is seen that the students place what they say and do in the left section of the template, and in the right section they make deductions according to the information they get from the user.

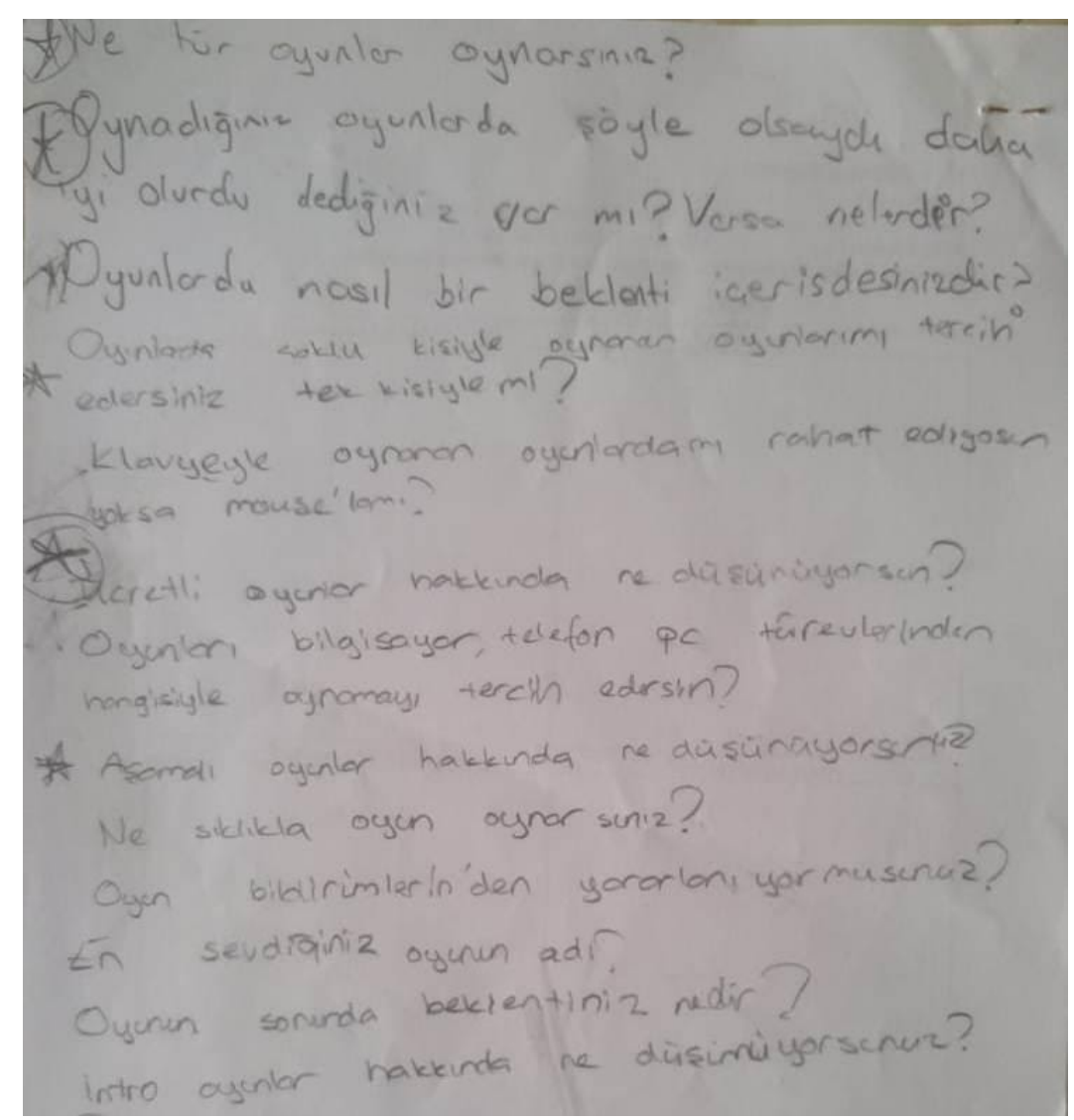

Figure 2. Example interview questions 


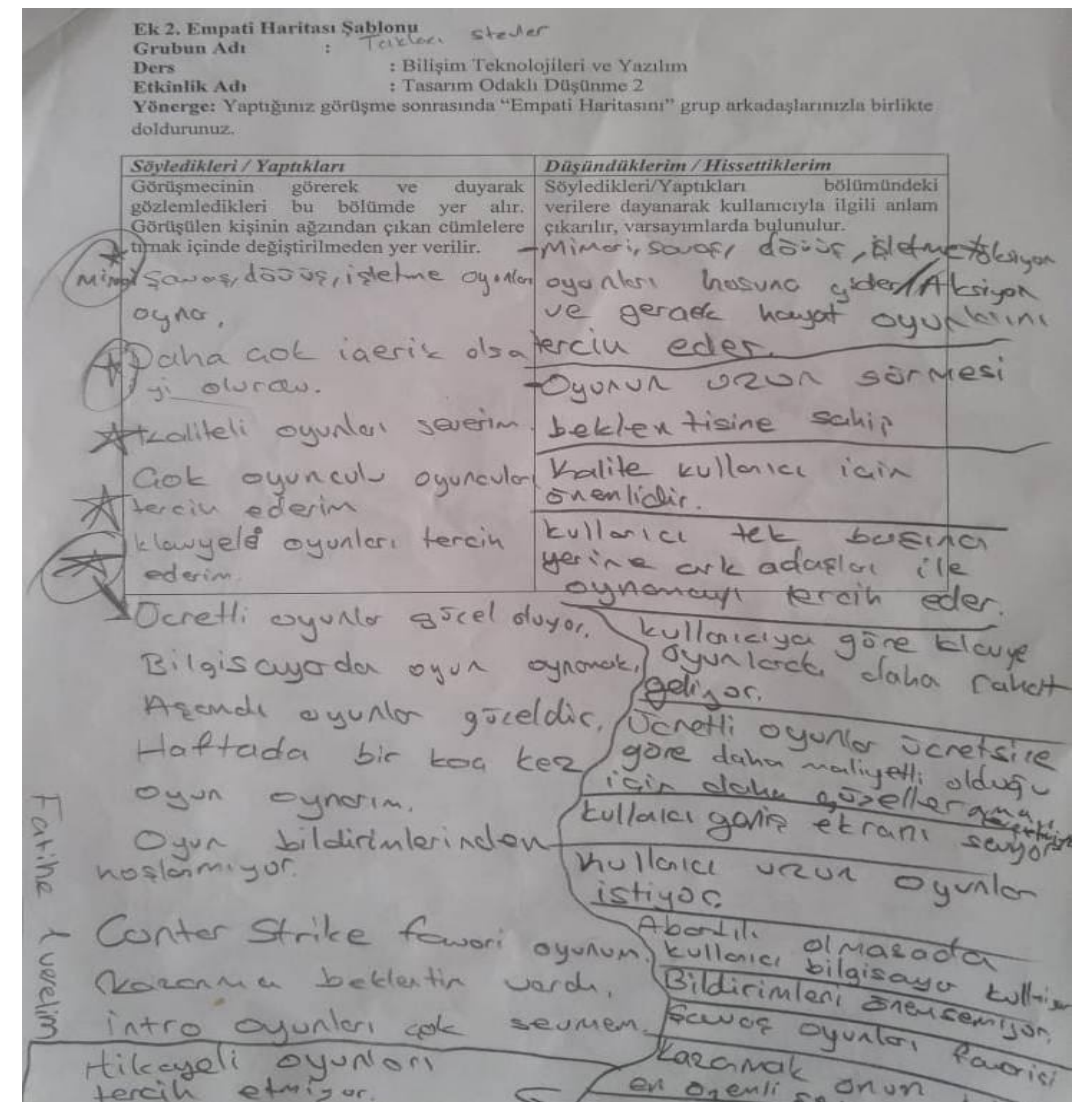

Figure 3. Example Empathy Map

\section{Execution Phase-Defining}

This is the phase where the problem or need is defined. Groups filled their POV worksheets in 15 minutes. In the Defining phase, students are asked to write down at least 3 POV statements. Each group is required to share POV statements to the class by one spokesperson and a discussion is held to check if the statements are correct POV statements. After that, students are asked to select one POV statement and proceed to the prototyping phase with that. When the POV template given in Figure 4 for the first DT task is examined, it is seen that the students write the user's need in the first part of the template by using verbs and in the second part they develop insight towards the need written in this statement. 


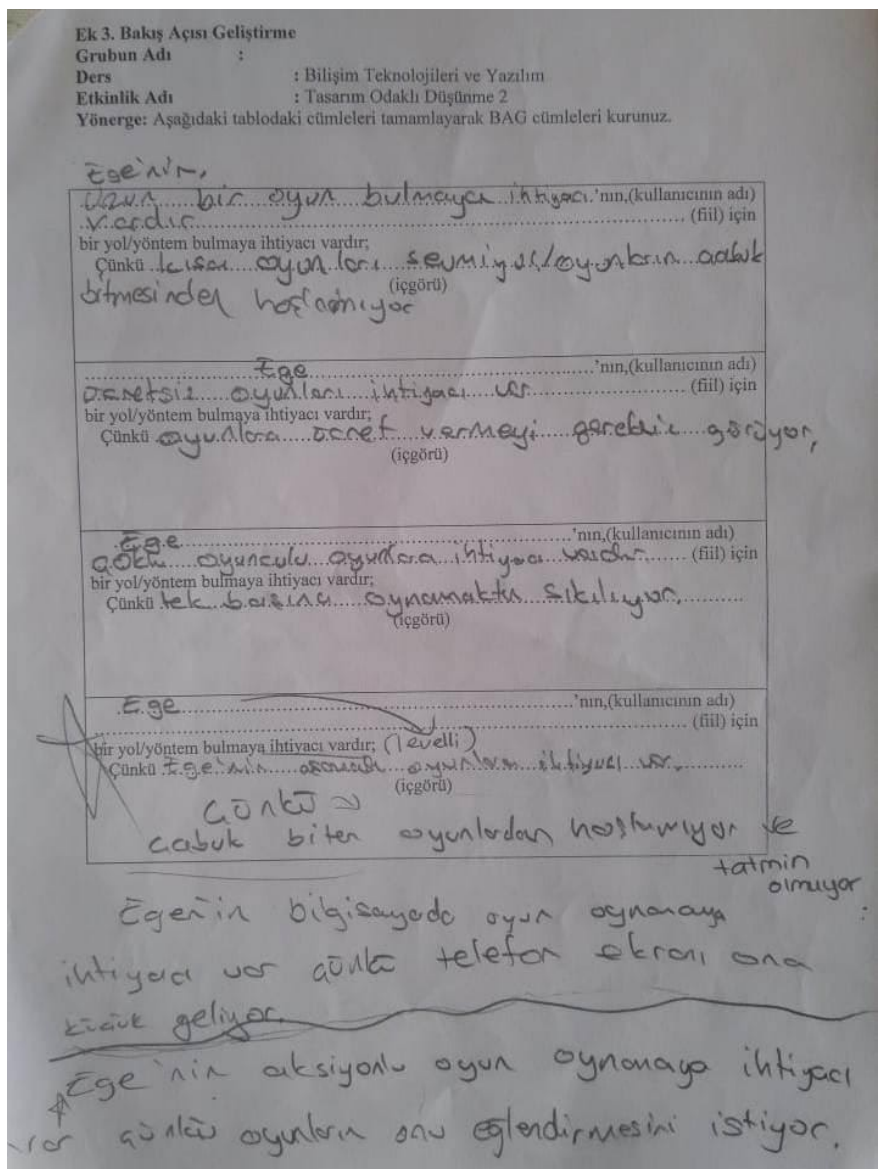

Figure 4. Example POV statements

\section{Execution Phase- Brainstorming}

After students write their POV statements, they do brainstorm to provide a solution for the need that presented itself in these statements. Before starting the brainstorming phase, students are reminded that they can develop each other's ideas (in their group), that ideas should not be judged, that the quantity of ideas is important, and that it is important for everyone to listen to each other's ideas. Students are given 10 minutes to produce at least 25 ideas. The students write down their ideas on sticky papers and cluster the papers in a dedicated area. Afterwards, if they wish to do so, students can cluster their ideas into categories. The images of the students' process of brainstorming are shared in Figure $5(\mathrm{a}, \mathrm{b})$. The activity leader(s) check whether the ideas that the students produce are solutions to the needs of the user and count the ideas. All members of the group which produced the most ideas receive a badge called "Ideate Card" by the activity leader(s). At the end of the brainstorming process, the group members put their signatures on 
the 3 ideas they liked the most. Thus, the idea on the sticky paper with the most signatures is determined and prototype development phase starts.

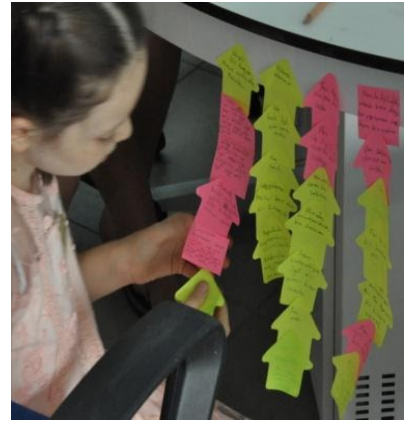

a

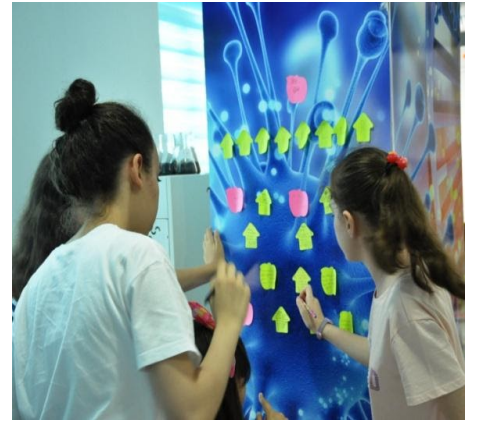

b

Figure 5. Brainstorming process

\section{Execution Phase -Prototyping}

Students develop prototypes for their chosen ideas at this phase by using the appropriate programming environment as well as tools and materials that are suitable to the DT task given. The prototypes developed by students for the DT tasks are presented in Figure $6(a, b)$, Figure 7, Figure $8(a, b)$, Figure $9(a, b)$ and Figure $10(a, b)$.

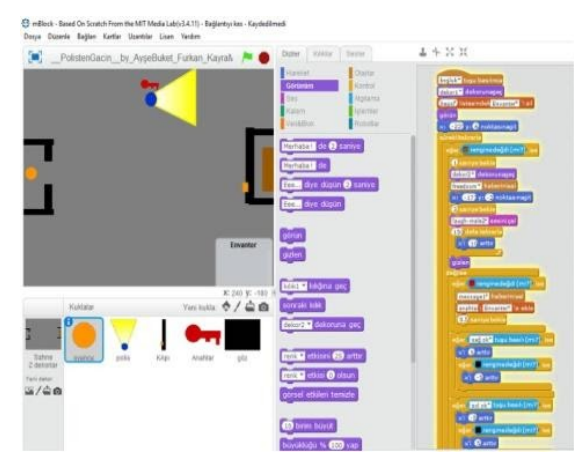

a

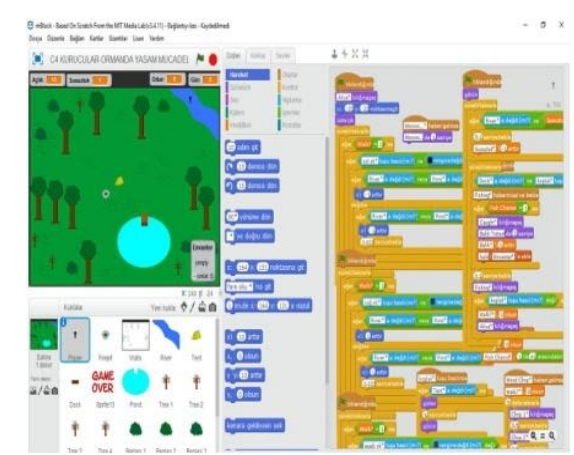

b

Figure 6. Example prototypes developed for 1st DT task

Figure 6 shows the prototypes developed by students in the Scratch block-based programming environment for the DT task. In Figure 6-a, a fast-progressive game was developed which has objectives and a story for the user. In this prototype, the user is imprisoned in a room. By using 
directional keys to move, the user tries to get to the key without touching the police character. When the key is taken, the door of the room opens and the character becomes free. The group who designed the second game developed a survival game for their users. In this game, the user is hunting in a forest, collecting goods, building houses, lighting fire and so on to survive (6b).

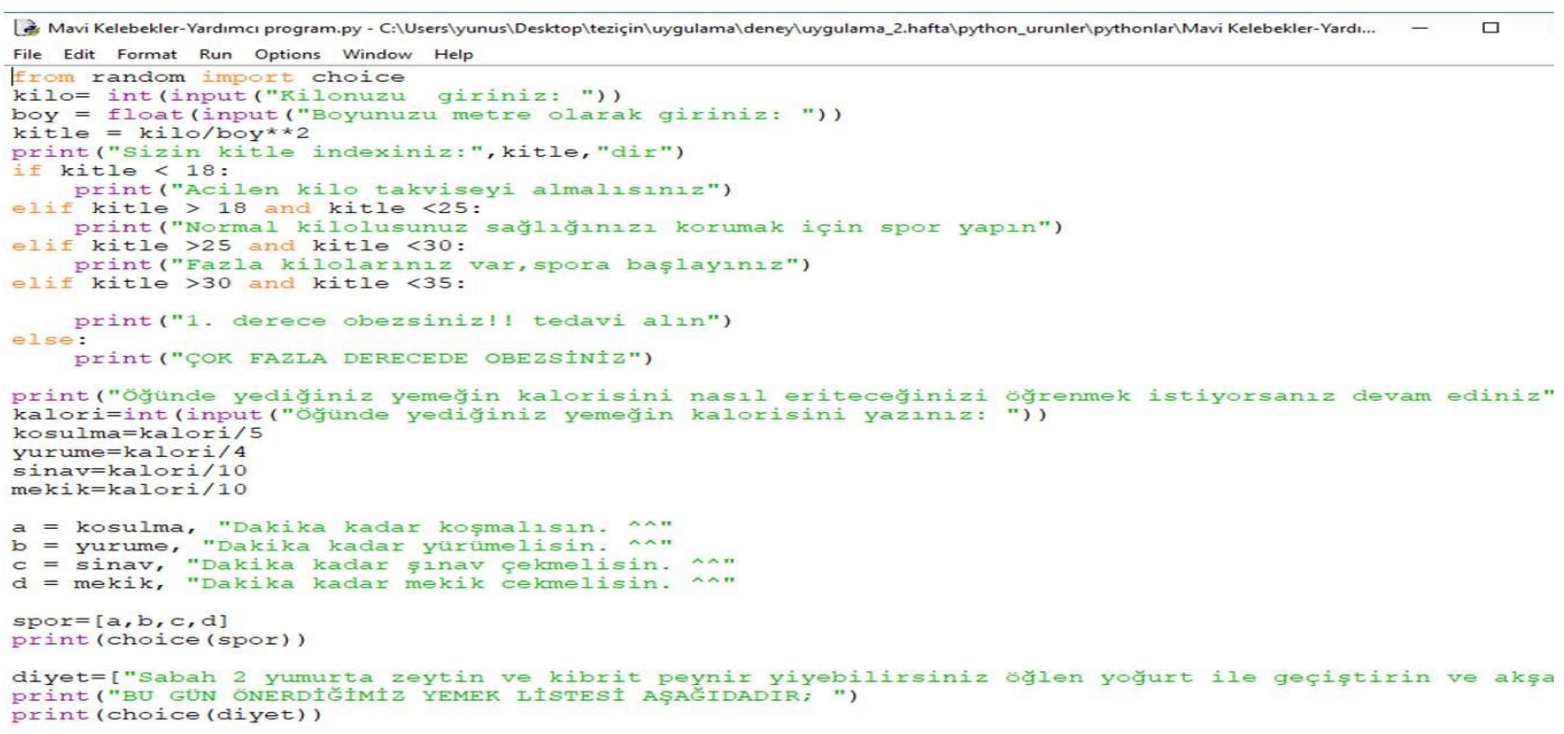

Figure 7. Example prototypes developed for 2nd DT task

Figure 7 shows the codes of the program that the students developed in Python programming language to redesign the healthy eating experience related to the second DT task. When the codes are examined, it can be seen that the user is asked to input their height and weight information. According to the information entered by the user, the program calculates the body mass index and returns feedback to the user. The user is then asked about the calories of the meal he or she eats for one meal course. According to this information, a suggestion is provided to the user regarding which sports to do and how long they should do it for in order to burn the target number of calories. A food menu is also offered to user. 


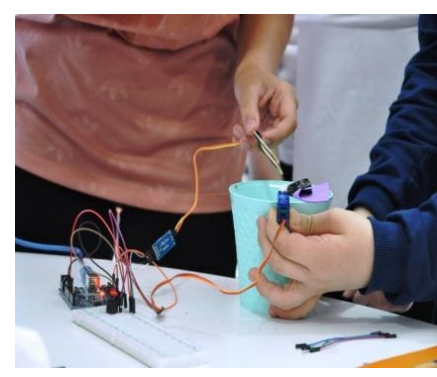

a

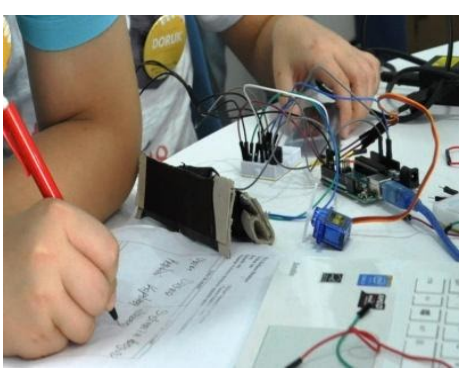

b

Figure 8. Example prototypes developed for 3rd DT task

Figure 8-a shows that a prototype has been developed to prevent user's unnecessary plant watering. The soil moisture sensor is used to measure the moisture value of the plant soil and the user is informed if the plant is in need of water. In Figure 8-b, a system is developed for the user's concerns about possible water shortages in the future. If the tap is opened too much, the user is warned by sound. This system automatically switches itself off when the tap is left open thanks to the programmed timer and it can be integrated into any kind of tap (Figure 8-b).

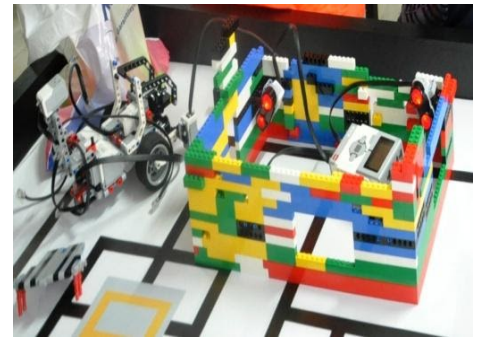

$\mathbf{a}$

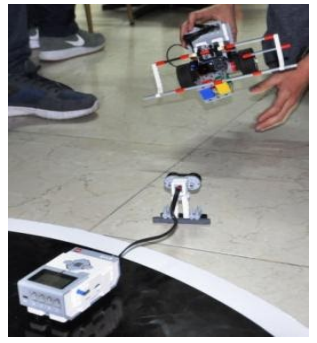

b

Figure 9. Example prototypes developed for 4th DT task

In Figure 9-a, a safe home system was developed, and in Figure 9-b, a robotic system was developed which can communicate with the police quickly using wireless technology in emergency situations. 


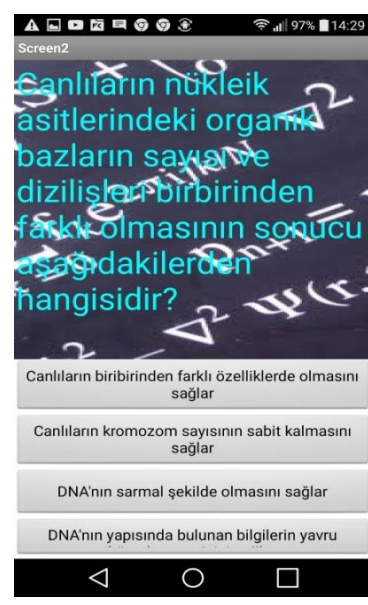

a

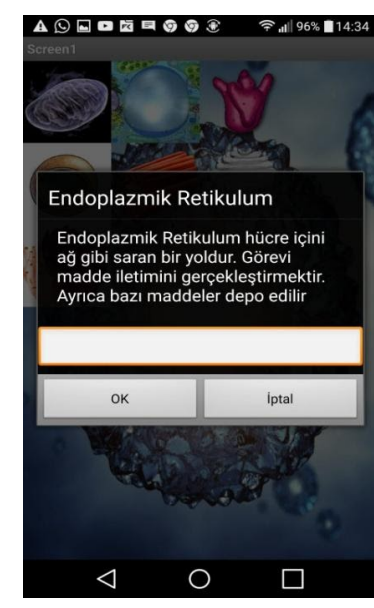

b

Figure 10. Example prototypes developed for 5th DT task

In the first prototype, a mobile application was developed that asks the user questions about science and technology lesson contents when the user shakes the phone, and gives feedback to users regarding their answers (Figure 10-a). In the second prototype, an application was developed that asks the user to input functions of organelles in the cell, and after the user provides their answer, the app informs the user according to the information entered (Figure $10-b)$.

\section{Execution Phase-Testing}

In the testing phase, the developed prototype is presented to the user and the user's feedback is received. This process provides information regarding whether the developed prototype meets the needs of the user or not. In the testing phase, there are some rules that both the designers and users need to pay attention to. Designers are required to briefly explain their prototype without sharing details, and allow the user to interact with the prototype without interrupting. They observe user carefully. Users; express their views about the prototype clearly and in a straightforward way. They explain all of the details they liked and disliked, and they behave clearly and honestly in this process. Group records the feedback of users by using the User Feedback Template. After reviewing the feedback, they received and making revisions on the prototype, their work is presented to the user again, and then the final version of prototype is shared. Figure 11 presents an example of a user feedback template filled in for the 1st DT task. 


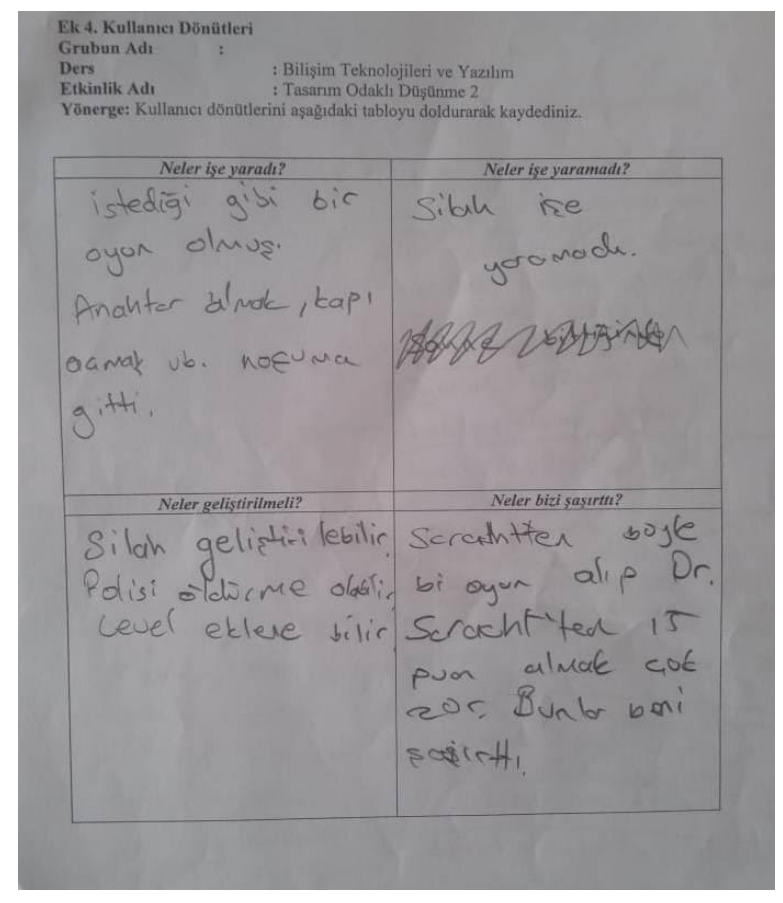

Figure 11. Example User Feedback Template

\section{Data Analysis}

The DT rubric was scored by 2 instructors during the implementation of the activities and compliance between the raters was evaluated. The intra-class correlation coefficient (ICC) was calculated for the compliance between the raters and this value was obtained as .825 . According to Koo and Li (2016, p.158), the ICC found between 0.75 and 0.90 is indicative of sufficient reliability. The boxes in the DT Observation Form are marked with the level of which gifted students are involved in the DT phases. For DT observation form, the compliance between the observers was examined by calculating "Weighted Kappa Coefficient" and this value was calculated as .68. Accordingly, there is a sufficient level of compliance among the observers and this value shows that results are purged from the chance factor (Şencan, 2005). Conducted interviews examined through content analysis.

\section{FINDINGS AND DISCUSSION}

Design thinking worksheets (Empathy Map, POV statements, User Feedbacks), note sheets used in the brainstorming process and prototypes developed during the DT process were 
examined with DT Rubric. In Table 1, the scores obtained from the criteria of DT rubric are shared.

Table 1

Groups' Scores from Each Criteria of DT Rubric

\begin{tabular}{|c|c|c|c|c|c|c|c|c|c|c|c|c|c|c|c|c|c|c|c|c|c|c|c|c|c|}
\hline \multirow[b]{2}{*}{ 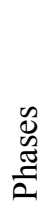 } & \multicolumn{5}{|c|}{ DT 1} & \multicolumn{5}{|c|}{ DT 2} & \multicolumn{5}{|c|}{ DT 3} & \multicolumn{5}{|c|}{ DT 4} & \multicolumn{5}{|c|}{ DT 5} \\
\hline & $\begin{array}{c}\mathbf{G} \\
\mathbf{1}\end{array}$ & $\begin{array}{c}\mathbf{G} \\
2\end{array}$ & $\begin{array}{c}\mathbf{G} \\
\mathbf{3}\end{array}$ & $\begin{array}{c}G \\
4\end{array}$ & $\begin{array}{l}G \\
5\end{array}$ & $\begin{array}{c}\mathbf{G} \\
1\end{array}$ & $\begin{array}{c}\mathbf{G} \\
2\end{array}$ & $\begin{array}{c}\mathbf{G} \\
\mathbf{3}\end{array}$ & $\begin{array}{c}G \\
4\end{array}$ & $\begin{array}{c}\mathbf{G} \\
5\end{array}$ & $\begin{array}{c}\mathbf{G} \\
\mathbf{1}\end{array}$ & $\begin{array}{c}\mathbf{G} \\
2\end{array}$ & $\begin{array}{c}\mathbf{G} \\
\mathbf{3}\end{array}$ & $\begin{array}{c}G \\
4\end{array}$ & $\begin{array}{c}\mathbf{G} \\
\mathbf{5}\end{array}$ & $\begin{array}{c}G \\
1\end{array}$ & $\begin{array}{c}\mathbf{G} \\
2\end{array}$ & $\begin{array}{c}\mathbf{G} \\
\mathbf{3}\end{array}$ & $\begin{array}{c}G \\
4\end{array}$ & $\begin{array}{l}G \\
5\end{array}$ & $\begin{array}{c}G \\
1\end{array}$ & $\begin{array}{c}\mathbf{G} \\
2\end{array}$ & $\begin{array}{c}\mathbf{G} \\
\mathbf{3}\end{array}$ & $\begin{array}{c}G \\
4\end{array}$ & $\begin{array}{l}\mathbf{G} \\
5\end{array}$ \\
\hline $\mathbf{E}$ & 3 & 3 & 4 & 4 & 4 & 3 & 4 & 4 & 3 & 3 & 4 & 3 & 2 & 4 & 4 & 4 & 4 & 3 & 4 & 4 & 4 & 4 & 4 & 3 & 4 \\
\hline D & 4 & 4 & 4 & 4 & 4 & 4 & 4 & 4 & 4 & 4 & 4 & 4 & 4 & 4 & 4 & 4 & 4 & 4 & 4 & 4 & 4 & 4 & 4 & 4 & 4 \\
\hline B & 4 & 4 & 4 & 4 & 4 & 4 & 4 & 4 & 4 & 4 & 4 & 4 & 4 & 4 & 4 & 4 & 4 & 4 & 4 & 4 & 4 & 4 & 4 & 4 & 4 \\
\hline $\mathbf{P}$ & 4 & 4 & 4 & 4 & 4 & 4 & 4 & 4 & 4 & 4 & 4 & 4 & 4 & 4 & 4 & 4 & 4 & 4 & 4 & 4 & 4 & 4 & 4 & 4 & 4 \\
\hline$T^{1}$ & 4 & 3 & 4 & 4 & 3 & 3 & 3 & 4 & 3 & 3 & 3 & 3 & 4 & 4 & 4 & 4 & 3 & 3 & 4 & 4 & 4 & 4 & 4 & 3 & 4 \\
\hline$T^{2}$ & $\overrightarrow{0}$ & $\infty$ & $\tilde{\sigma}$ & $\stackrel{N}{O}$ & $\overrightarrow{0}$ & $\infty$ & $\overrightarrow{0}$ & $\stackrel{N}{O}$ & $\overrightarrow{0}$ & $\infty$ & $\bar{\sigma}$ & $\bar{\infty}$ & $\infty$ & N & $\stackrel{N}{O}$ & 응 & $\overrightarrow{0}$ & $\varpi$ & $\stackrel{N}{O}$ & $\stackrel{N}{O}$ & $\stackrel{N}{O}$ & N & N & $\infty$ & $\stackrel{N}{O}$ \\
\hline$\overline{\mathbf{X}}$ & \multicolumn{5}{|c|}{19.2} & \multicolumn{5}{|c|}{18.8} & \multicolumn{5}{|c|}{19} & \multicolumn{5}{|c|}{19.4} & \multicolumn{5}{|c|}{19.6} \\
\hline
\end{tabular}

* G: Group, E: Empathy, D: Defining, B: Brainstorming, $\mathrm{P}=$ Prototyping, $\mathrm{T}^{1}=$ Testing, $\mathrm{T}^{2}=$ Total Score, $\overline{\mathrm{X}}$ : Groups' Average Points for All Design Tasks

When Table 1 is examined, it shows the scores obtained from the criteria of DT rubric of the 5 different groups (group members change in each design task) related to DT tasks and the average of scores of 5 groups for each design task. The average scores of the groups from the 1st DT Task was 19.2, for the 2nd DT Task average was 18.8, for the 3rd DT Task it was 19, for the 4th DT Task it was 19.4 and finally for the 5th DT Task the average score was 19.6. It can be said that the groups scored higher than the DT Rubric.

Using the DT Observation Form, observations were conducted for eight lesson hours. The behaviors that enable students to demonstrate their skills in DT phases were examined by the observation form. When the behaviors related to empathy phase are examined; it was understood that students exhibited behaviors at Level $2(n=2)$, Level $3(n=14)$ and Level $4(n$ =9). Again, in the defining phase, students showed behaviors at Level $2(n=4)$, Level $3(n=$ 16) and Level $4(n=5)$. In the process of brainstorming and prototyping, students presented the behaviors in Level 3 and Level 4. 12 students are in Level 3 and 13 students are in Level 4 in the phase of brainstorming. During the prototyping phase, 17 students are at Level 3 and 8 
students are at Level 4 . In the last phase of the test; 8 students showed behaviors belonging to Level 2, 11 students in Level 3 and 6 students in Level 4.

During the semi-structured interviews with four gifted students both prior and after the activities, they highlighted the tools of prototyping, DT process and features of designers. After execution of activities, as distinct from their prior thoughts, students mentioned that they learned the process, shared the results, enjoyed the experience, made their POV statements and repeated the phases during the process. As for prototyping tools; programming tools like Scratch, Appinventor etc., 3D design software and easy-to-find tools (cardboard, drinking straw, crepe paper, etc.) are mentioned. According to the students' views, a good designer should be able to empathize, work with teams, value the thinking process, and respect others' ideas. The fact that these characteristics of designers are mentioned only after the execution of the activities can be explained by effects of activities on the students' thoughts about the designer characteristics.

There is no study in literature that states and search upon DT activities implemented on gifted students specifically and the effects of activity achievements to students. Ayverdi (2018) used the Engineering Design Cycle in the STEM events, which is similar to the DT process. In the same study, as a result of the implementation of STEM activities, it was determined that the engineering skills of gifted students improved and the students enjoyed participating in the activities. In literature, there are studies that show DT activities implemented on ordinary students and achievements of students are examined. Duman and Kayal1 (2017) executed DT ordinary students and it is found that activities applied to secondary school students were successful in terms of improving their DT skills. Aflatoony et al. (2018) state that DT skills of high school students have improved to a certain level as a result of the activities implemented. In other studies, as a result of the DT process, students learned academic content (Carroll et al., 2010; Carroll, 2015; Kwek, 2011; Painter, 2018) and had problems working with the team (Santos Ordóñez, González Lema and Miño Puga, 2017, Retna, 2016) and students enjoyed participating in DT process (Dukes and Koch, 2012). The results obtained in studies in literature and the results of this study support each other. During the implementation process of activities, students have chance to improve 21 st century skills in the phases of empathy, defining, brainstorming, prototyping and testing (Henriksen et all., 2017). Many studies provide evidence that DT activities improve 21 st century skills (Carroll, 2015; Diefenthaler, Moorhead, Speicher, Bear and Cerminaro, 2017; Koh et al., 2015; Scheer et al., 2011). The development of students' 
DT skills after the implementation of the activities in this study is also a supportive indicator of this situation.

\section{CONCLUSION AND SUGGESTIONS}

After the execution of the DT activities, students stated in the interviews that they enjoyed DT activities, they learned the process, they had small arguments with team members during design process and it is hard to work with a team. After participating in DT process, students shaped the characteristics of a good designer according to their DT experiences, and concluded that a good designer should be able to work with a team and should be a respectful person. It is thought that obstacles experienced regarding the team work may result from almost all gifted students' tendency to be a leader and desire to manage team on their own. Additionally, the situations of some students being outsider to team work, not fulfilling their duties and not respecting to opinions of peers caused to having problems. Based on teacher observations, majority of students exhibit the behaviors of Level 3. Scores of students obtained from DT Rubric are also very high. At the end of execution of activities, it is observed that gifted students have improved their DT skills, learned the academic content and experienced some problems regarding working with the team.

For further studies, activities may develop to place DT thinking ways in detail. Students' roles like teamwork, participation in the DT process may be observed in detail more. The process used by the gifted students to reach the solutions for the design problems and their creativity levels can be investigated in detail. During the interviews with the students; collaboration can be portrayed like solidarity, good or bad in teamwork, contribution to the team and so on. The maximum number of students in a group should be 5 and the leadership skills of gifted students should be taken into account in group work. To increase the motivation of students in the process of brainstorming, the principles of gamification can be utilized such as giving badges to the group that produced the most amount of ideas. While DT is applied in programming teaching processes, block-based programming environments such as Scratch, Mblock and App Inventor, text-based programming environments such as Python, Arduino IDE, and for physical programming Lego Mindstorms and Arduino tools can be preferred.

\section{Acknowledgements}

This study was conducted by first author from his doctoral thesis under the supervision of the second author and funded by Balıkesir University (2018/066). 
Özel Yetenekli Öğrencilere Programlama Öğretiminde Tasarım Odaklı Düşünme Uygulamaları

\begin{abstract}
Özet
Çalışmanın amacı; tasarım odaklı düşünmenin (TOD) özel yetenekli öğrencilere programlama öğretimi süreçlerinde nasıl uygulanabileceğinin ve öğretim sürecine olan etkilerinin ortaya konulmasıdır. Araştırmada durum çalışması (örnek olay) yöntemi kullanılmıştır. Yapılandırılmamış bir probleme, programlama araçları ve TOD süreci kullanılarak çözüm üretmeye yönelik olarak 5 farklı TOD görevi tanımlanmıştır. TOD etkinlikleri, yaz döneminde, il merkezinde bulanan bir Bilim ve Sanat Merkezi'nde (BILLSEM) 25 özel yetenekli (13 kız, 12 erkek) öğrenciye uygulanmıştır. Veriler araştırmacılar tarafından geliştirilen TOD Rubriği, görüşme ve gözlem formu kullanarak toplanmıştır. Araştırmanın sonuçları özel yetenekli öğrencilerin TOD becerilerini belirli bir seviyeye kadar geliştirdikleri, akademik içeriği öğrendikleri, süreçten keyif aldıkları ve takımla çalışma konusunda birtakım sıkıntılar yaşadıklarını göstermiştir. Uygulama süreci sonunda öğrenciler, iyi bir tasarımcının takımla çalışabilen saygılı birisi olması gerektiğini vurgulamışlardır. Ayrıca, öğrenci görüsslerine göre Scracth, Arduino IDE, Lego Mindstorms EV3 gibi farklı programlama araçları ve ortamları TOD sürecinin prototipleme aşamasında kullanılabilir. TOD etkinliklerinin TOD düşünme şekillerine yer verecek şekilde güncellenmesi ve uygulama sürecinde özel yetenekli öğrencilerin liderlik özelliklerinin dikkate alınması önerilebilir.
\end{abstract}

Anahtar kelimeler: tasarım odaklı düşünme, farklılaştırma, özel yetenekli öğrenci, programlama, etkinlik tasarım.

\begin{abstract}
About the Authors
Yunus Emre Avcu

Yunus Emre Avcu is a computer science teacher at Şehit Prof. Dr. İlhan Varank Science and Art Center (BILLSEM). He has been working with gifted students for six years. He received his BA in Computer Education \& Instructional Technology Department and MS in Curriculum and Instruction Department at Çanakkale On Sekiz Mart University. He gained a Ph.D. in Curriculum and Instruction Department at Balıkesir University in November 2019. His interest areas are gifted education, differentiation, creativity, design thinking, computational thinking, instructional design, programming, and using technology in gifted education.
\end{abstract}

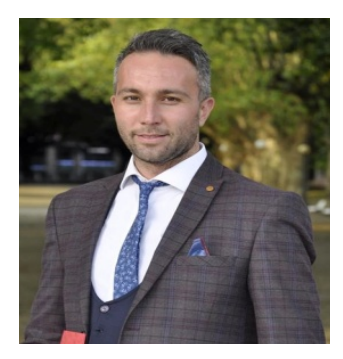

Mailing Address: Şehit Prof. Dr. İlhan Varank Art and Science Center, Balıkesir, Turkey, 10020 E-mail: yunus1099@hotmail.com

\section{Kemal Oğuz Er}

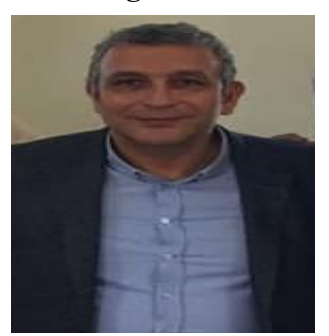

Kemal Oğuz Er is Associative Professor of Curriculum and Instruction Department at Balıkesir University. Dr. Er received his BA and MS in Curriculum and Instruction Department at Hacettepe University and Ohio University respectively. He gained a Ph.D. in Curriculum and Instruction department at Ankara University in 2006. His interest areas are curriculum design, program evaluation, teacher education, comparative studies and philosophical, historical and social foundations of education.

Mailing Address: Balıkesir University, 10100, Balıkesir, Turkey

E-mail: keoguzer@gmail.com

\title{
REFERENCES
}

Aflatoony, L., Wakkary, R., \& Neustaedter, C. (2018). Becoming a design thinker: assessing the learning process of students in a secondary level design thinking course. The 
International Journal of Art \& Design Education, 37(3), 438-453. DOI: $10.1111 /$ jade. 12139

Alhusaini, A. (2018). Using the TASC model to develop gifted students' creativity: Analytical review. Journal for the Education of Gifted Young Scientists, 6(3), 10-29. DOI: http://dx.doi.org/10.17478/JEGYS.2018.78

Andrade, H. G. (2000). Using rubrics to promote thinking and learning. Educational Leadership, 57 (5), 13-18.

Ataman, A. (2004). Üstün Zekâlı ve Üstün Özel Yetenekli Çocuklar. M. Şirin., A. Kulaksızoğlu., \& A. Bilgili (Eds.), Türkiye Üstün Yetenekli Çocuklar Kongresi Seçilmiş Makaleler Kitabı içinde (ss.155-168). İstanbul: Çocuk Vakfı Yayınları.

Ayverdi, L. (2018). Özel Yetenekli Öğrencilerin Fen Eğitiminde Teknoloji, Mühendislik ve Matematiğin Kullanımı: FETEMM Yaklaşımı. Yayınlanmamış Doktora Tezi, Balıkesir Üniversitesi Fen Bilimleri Enstitüsü, Balıkesir.

Bootcamp Bootleg D. School (2011). Design thinking. Retrieved from http://longevity3.stanford.edu/designchallenge2015/files/2013/09/Bootleg.pdf

Bouchard, J. (2013). Design Thinking: Exploring Creativity in Higher Education. Unpublished Master's Thesis, Master of Arts, Michigan State University, USA.

Brown, T., \& Wyatt, J. (2010). Design thinking and social innovation. Stanford Social Innovation Review, Winter, 30-35.

Carroll, M., Goldman, S., Britos, L., Koh, J., Royalty, A., \& Hornstein, M. (2010). Destination, imagination and the fires within: Design thinking in a middle school classroom. International Journal of Art \& Design Education, 29 (1), 37-53.

Carroll, M. (2014). Shoot for the moon! The Mentors and the middle schoolers explore the intersection of design thinking and STEM. Journal of Pre-College Engineering Education Research (J-PEER), 4(1), 14-30. DOI: https://doi.org/10.7771/21579288.1072 
Carroll, M. (2015). Stretch, dream, and do - a 21st century design thinking \& STEM journey. Journal of Research in STEM Education, 1 (1), 59-70.

Chesson, D. (2017). The Design Thinker Profile: Creating and Validating a Scale for Measuring Design Thınking Capabilities. Unpublished Doctoral Thesis, Antioch University, Ohio, USA.

Clark, B. (2015). Üstün Zekâlı Öğrencileri Anlamak. In F. Kaya., Ü. Ogurlu (Eds.), Üstün Zekâlı Olarak Büyümek içinde (ss.1-34). Ankara: Nobel Akademik Yayıncılık.

Crane, A. (2018). Exploring Best Practices for Implementing Design Thinking Processes in K12 Education. Unpublished Master's Thesis, University of Kansas, USA.

Darbellay, F., Moody, Z., \& Lubart, T. (2017). Introduction: Thinking Creativity, Design and Interdisciplinarity in a Changing World. In F. Darbellay, Z. Moody \& T. Lubart (Eds.), Creativity, Design Thinking and Interdisciplinarity (pp.xi-xx ), New York: Springer.

Diefenthaler, A., Moorhead, L., Speicher, S., Bear, C., \& Cerminaro, D. (2017). Thinking \& Acting Like a Designer: How Design Thinking Supports Innovation in K-12 Education. Retrieved from https://hfli.org/app/uploads/2017/11/Thinking-and-Acting-Like-ADesigner-\%E2\%80\%93-DT-in-K-12-education-\%E2\%80\%93-IDEO-WISE-1.pdf

Dosi, C., Rosati, F., \& Vignoli, M. (2018, May). Measuring design thinking mindset. Paper presented at 15th International Design Conference, Dubrovnik, Crotia. DOI: https://doi.org/10.21278/idc.2018.0493.

Duman, B., \& Kayalı, D. (2017). Teknopedagojik Öğretme Yaklaşımının Tasarım Odaklı Düşünme Becerilerine Etkisi. B. Akkoyunlu, A. İşman, \& H. F. Odabaşı (Eds.), Eğitimde Teknoloji Okumalart 2018 içinde (ss.176-184). Ankara: TOJET. DOI: http://dx.doi.org/10.14527/9786053183563b2.012

Gür, Ç. (2017). Eğitimsel ve Sosyal-Duygusal Bakış Açısıyla Üstün Yetenekli Çocuklar. Ankara: Anı Yayıncıl1k.

Henriksen, D., Richardson, C., \& Mehta, R. (2017). Design thinking: A Creative approach to educational problems of practice. Thinking Skills and Creativity, 26, 140-153. DOI: http://dx.doi.org/10.1016/j.tsc.2017.10.001 
Ideate High Academy. (2019). Design Thinking. Retrieved from https://ideatehighacademy.com/design-thinking/

Jonassen, D. H. (2000). Computers As Mindtools For Schools: Engaging Critical Thinking. New Jersey, USA: Prentice Hall.

Kanlı, E. (2008). Fen ve Teknoloji Öğretiminde Probleme Dayalı Öğrenmenin Üstün ve Normal Zihin Düzeyindeki Öğrencilerin Erişi, Yaratıcı Düşünme ve Motivasyon Düzeylerine Etkisi. Yayınlanmamış Yüksek Lisans Tezi, İstanbul Üniversitesi Sosyal Bilimler Enstitüsü, İstanbul.

Kelley, T., \& Kelley, D. (2013). Creative Confidence: Unleashing The Creative Potential Within Us All. New York: Random House Company.

Kert, S. B. (2018). Programlama Öğretimi İçin Pedagojik Yaklaşımlar. Y. Gülbahar \& H. Karal (Eds.), Kuramdan Uygulamaya Programlama Öğretimi (ss.93-130). Ankara: Pegem Akademi. DOI: 10.14527/9786052415092

Koh, J. H. L., Chai, C. S., Wong, B., \& Hong, H. (2015). Design Thinking for Education: Conceptions and Applications in Teaching and Learning. Singapore: Springer. DOI: https://doi.org/10.1007/978-981-287-444-3.

Koo, T. K., \& Li, M. Y. (2016). A guideline of selecting and reporting intraclass correlation coefficients for reliability research, Journal of Chiropractic Medicine, 15, 155-163. DOI: https://doi.org/10.1016/j.jcm.2016.02.012

Kwek, S.H. (2011). Innovation in the Classroom: Design Thinking for 21st Century Learning. Unpublished Master's Thesis, Standford University, USA. Retrieved from www.stanford.edu/group/redlab/cgibin/publications_resources.php

Lor, R. R. (2017, May). Design thinking in education: a critical review of literature. Paper presented at Asian Conference on Education \& Psychology, Bangkok, Thailand.

Maker, C. J., \& Pease, R. (2008). DISCOVER and TASC in a summer program for gifted students. Gifted Education International, 24(2-3), 323-328.

Maker, J. C., \& Schiever, S. W. (2005). Teaching Models in Education of the Gifted. Austin, TX: Pro-Ed. 
Marland, S. P. (1972). Education of the Gifted and Talented. (2 Vols.). Report to congress of the United States Commissioner of Education, Washington, DC: US Government Printing Office.

Merriam, S. B. (2014). Qualitative Research: A Guide to Design and Implementation. Somerset, US: Jossey-Bass.

Mertler, C. A. (2001). Designing scoring rubrics for your classroom. Practical Assessment, $\begin{array}{llll}\text { Research } \& \text { Evaluation, } & \text { Retrieved }(25) \text { from }\end{array}$ http://www.pareonline.net/getvn.asp?v=7\&n=25

Ministry of National Education (MoNE). (2017). BILLSEM Bilişim Teknolojileri ve Yazılım Dersi Çerçeve Programı [BİLSEM Information Technologies and Software Lesson Framework Program]. Retrieved from http://bilsem.meb.gov.tr/login.aspx

Ministry of National Education (MoNE). (2018). Özel Ĕgitim Hizmetleri Yönetmeliği [Special Education Services Regulation]. Retrieved from ttp://www.resmigazete.gov.tr/eskiler/2018/07/20180707-8.htm

Ministry of National Education (MoNE). (2019). Özel Yetenekliler İçin Bilişim Teknolojileri ve Yazılım Dersi Öğretim Programı (5,6,7 ve 8. Sinıflar) [Information Technologies and Software Lesson Teaching Program for Gifted (Grades 5, 6, 7 and 8)]. Retrieved from http://mufredat.meb.gov.tr/TaslakProgramlar.aspx

National Association of Gifted Children (NAGC). (2019). What is giftedness? Retrived from http://www.nagc.org/resources-publications/resources/what-giftedness

Noel, L., \& Liub, T. (2017). Using design thinking to create a new education paradigm for elementary level children for higher student engagement and success. Design and Technology Education: An International Journal, 1(22), 501-512.

Odabaşı, H. F., Dursun, Ö. Ö., Ersöz, R. A., \& Kılınç, H. (2018). Öğretmen Eğitiminde Yeni Bir Yaklaşım: Tasarımcı düşünme. B. Akkoyunlu, A. İşman, \& H. F. Odabaşı (Eds.). Eğitimde Teknoloji Okumaları 2018 içinde (ss.392-424). Ankara: TOJET. 
Öngöz, S., \& Sözel, H. K. (2018). Üstün Yeteneklilerin Eğitiminde Teknoloji Kullanımı. H. F. Odabaşı (Ed.). Özel Ĕgitim ve Eğitim Teknolojisi içinde (ss. 91-114). Ankara: Pegem Akademi. DOI: 10.14527/9786052411773

Painter, D. (2018). Using Design Thinking in Mathematics for Middle School Students: A Multiple Case Study of Teacher Perspectives. Unpublished Master's Thesis, Concordia University-Portland.

Plucker, J. A., \& Callahan C. M. (2014). Research on giftedness and gifted education. Exceptional Children, 80 (4), 390-406. doi: 10.1177/0014402914527244

Rauth, I., Köppen, E., Jobst, B, \& Meinel, C. (November, 2010). Design thinking: An educational model towards creative confidence. Paper presented at 1st International Conference on Design Creativity (ICDC2010), Kobe, Japan.

Renzulli, J. S. (1978). What makes giftedness? Reexamining a definition. Phi Delta Kappan, 60, 18-24.

Retna, K. S. (2016). Thinking about design thinking: A study of teacher experiences. Asia Pacific Journal of Education, 36 (1), 5-19. DOI: 10.1080/02188791.2015.1005049

Romero, M., Lepage, A., \& Lille, B. (2017). Computational thinking development through creative programming in higher education. International Journal of Educational Technology in Higher Education, 14 (42), 1-15. DOI 10.1186/s41239-017-0080-z

Root-Bernstein, R. S., \& Root-Bernstein, M. (1999). Sparks of Genius: The Thirteen Thinking Tools of the World's Most Creative People. New York: Houghton Mifflin.

Sak, U. (2014). Üstün Zekâlılar Özellikleri Tanılanmaları Eğitimleri. Ankara: Vize Yayıncılık.

Santos Ordóñez, A., González Lema, C., \& Miño Puga, M. F. (2017, July). Design thinking as a methodology for solving problems: contributions from academia to society. Paper presented at 15th LACCEI International Multi-Conference for Engineering, Education, and Technology: "Global Partnerships for Development and Engineering Education", Boca Raton Fl, United States. 
Scheer, A., Noweski, C., \& Meinel, C. (2012). Transforming constructivist learning into action: Design thinking in education. Design and Technology Education: An International Journal, 17(3), 8-19.

Şahin, F. (2015a). Üstün Zekâlı Öğrencilerin Eğitimine Yönelik Eğitsel Stratejiler. F. Şahin (Ed.), Üstün Zekâlı ve Üstün Yetenekli Öğrencilerin Ĕ̆itimi içinde (ss.1-15). Ankara: Pegem Akademi.

Şahin, F. (2015b). Genel Eğitim Sınıflarındaki Üstün Yetenekli Öğrencilerin Eğitiminde Müfredat Farkl1laştırma. F. Şahin (Ed.). Üstün Zekâlı ve Üstün Yetenekli Öğrencilerin Ĕ̌itimi içinde (ss.20-38). Ankara: Pegem Akademi.

Şahin, F. (2018a). Özel Yeteneklilerin Eğitimi Ĕ̈itsel Stratejiler ve Örneklerle Zenginleştirilmiş Müfredat Farklılaştırma Modelleri. Ankara: Nobel Yayıncılık.

Şahin, F. (2018b). Özel Yetenekli Öğrenciler ve Eğitimleri. F. Şahin (Ed.). Müfredat Modelleri (pp.65-104). Ankara: Anı Yayıncılık.

Şencan, H. (2005). Sosyal ve Davranışsal Ölçümlerde Güvenirlik ve Geçerlilik. Ankara: Seçkin Yayınc1lik.

Tomlinson, C.A. (1995). How to Differentiate Instruction in Mixed Ability Classrooms. Alexendria VA: Association for Supervision and Curriculum Development.

Tortop, H. S. (2015). Üstün Zekâlılar Ĕ̆itiminde Farklılaştırllmış Öğretim Müfredat Farklılaştırma Modelleri. Ankara: Genç Bilge Yayıncılık.

Treffinger, D. J., Jackson, J., \& Jensen, B. (1996). Future Problem Solving Program: Past, Present, and Future. Ann Arbor, MI: Future Problem Solving Program.

VanTassel-Baska, J. \& Brown, E. F. (2000). An Analysis of Gifted Education Curriculum Models. In F. A. Karnes, \& S. M. Bean (Eds.), Methods and Materials for Teaching the Gifted (pp.107-137). Waco, TX: Prufrock Press.

Wallace, B., Cave, D., Berry, A. (2009). Teaching Problem Solving and Thinking Skills Through Science. Abington, Oxon:Routledge. 


\section{Annexes}

\section{Annex 1. Empathy Map Template}

Group Name

Lesson : Information Technologies and Software

Activity Name

Instructions: After the interview, please fill out the "Empathy Map" with your group members.

\begin{tabular}{|l|l|}
\hline What They Said / Done & My Thoughts / Feelings \\
\hline $\begin{array}{l}\text { Interviewer's observations that are seen and heard } \\
\text { stated in this section. The sentences that come out of } \\
\text { the interviewee's mouth are included in the quotes } \\
\text { without being changed. }\end{array}$ & $\begin{array}{l}\text { Based on the data in the what they said / done section, } \\
\text { deductions are made about the user and assumptions } \\
\text { are noted. }\end{array}$ \\
$\ldots$
\end{tabular}

\section{Annex 2. POV Template}

Group Name

Lesson

: Information Technologies and Software

Activity Name :

Instructions: Make POV statements by completing the sentences in the table below.

$$
\text { ,'s,(user's name) }
$$

(verb) needs to find a way / method for that;

Because

\section{(insight)}

\section{Annex 3. User Feedback Template}

Group Name

Lesson

Activity Name

Instructions: Record user feedbacks by filling out below table.

\begin{tabular}{|c|c|}
\hline What worked out? & What did not work out? \\
\hline$\ldots$ & $\ldots$ \\
\hline What should be improved? & What has surprised us? \\
\hline$\ldots$ & $\ldots$ \\
& \\
\hline
\end{tabular}




\section{Annex 4. Design Thinking Rubric}

Group Name:

Design Thinking Task:

\begin{tabular}{|c|c|c|c|c|c|}
\hline & \multicolumn{5}{|c|}{ Levels } \\
\hline Criteria & $\begin{array}{c}1 \\
\text { (Weak) }\end{array}$ & $\begin{array}{c}2 \\
\text { (Moderate) }\end{array}$ & $\begin{array}{c}3 \\
\text { (Competent) }\end{array}$ & $\begin{array}{c}4 \\
\text { (Most Competent) }\end{array}$ & Score \\
\hline Empathy & $\begin{array}{c}\text { Interview } \\
\text { questions are } \\
\text { prepared proper } \\
\text { to the design } \\
\text { task and } \\
\text { directed to user }\end{array}$ & $\begin{array}{l}\text { The } \\
\text { information } \\
\text { gathered from } \\
\text { interview } \\
\text { noted } \\
\text { randomly }\end{array}$ & $\begin{array}{l}\text { The information } \\
\text { gathered from the } \\
\text { interview noted in } \\
\text { empathy template } \\
\text { by stating direct } \\
\text { sentences coming } \\
\text { from person's } \\
\text { mouth }\end{array}$ & $\begin{array}{l}\text { The information } \\
\text { gathered from the } \\
\text { interview was written } \\
\text { down in the empathy } \\
\text { template by including } \\
\text { the sentences coming } \\
\text { directly from the } \\
\text { mouth of the person } \\
\text { and the assumptions } \\
\text { about the user stated. }\end{array}$ & \\
\hline $\begin{array}{l}\text { Point of View } \\
\text { (POV) }\end{array}$ & $\begin{array}{l}\text { One proper and } \\
\text { clear POV } \\
\text { statement has } \\
\text { been written }\end{array}$ & $\begin{array}{c}\text { Two clear } \\
\text { POV } \\
\text { statements } \\
\text { have been } \\
\text { written partly } \\
\text { properly }\end{array}$ & $\begin{array}{c}\text { Three clear POV } \\
\text { statements have } \\
\text { been written almost } \\
\text { properly }\end{array}$ & $\begin{array}{c}\text { At least four clear } \\
\text { POV statements have } \\
\text { been written totally } \\
\text { properly }\end{array}$ & \\
\hline Brainstorming & $\begin{array}{l}0-5 \text { ideas } \\
\text { produced }\end{array}$ & $\begin{array}{l}\text { 5-15 ideas } \\
\text { produced }\end{array}$ & $\begin{array}{c}15-25 \text { ideas } \\
\text { produced }\end{array}$ & $\begin{array}{c}\text { More than } 25 \text { ideas } \\
\text { produced }\end{array}$ & \\
\hline Prototyping & $\begin{array}{l}\text { No unnecessary } \\
\text { things were } \\
\text { included in the } \\
\text { prototype, the } \\
\text { design was } \\
\text { partially } \\
\text { interesting and } \\
\text { visually } \\
\text { successful. }\end{array}$ & $\begin{array}{c}\text { No } \\
\text { unnecessary } \\
\text { things were } \\
\text { included in the } \\
\text { prototype, the } \\
\text { design was } \\
\text { very } \\
\text { interesting and } \\
\text { visually } \\
\text { successful. }\end{array}$ & $\begin{array}{l}\text { Easily used } \\
\text { prototype with no } \\
\text { unnecessary things } \\
\text { and the design was } \\
\text { very interesting and } \\
\text { visually successful }\end{array}$ & $\begin{array}{l}\text { Easily used prototype } \\
\text { with no unnecessary } \\
\text { things included and } \\
\text { the design was very } \\
\text { interesting and } \\
\text { visually successful } \\
\text { also enabled the user } \\
\text { interaction }\end{array}$ & \\
\hline Testing & $\begin{array}{c}\text { Prototype is } \\
\text { used by user } \\
\text { and it is noted } \\
\text { what has been } \\
\text { worked out }\end{array}$ & $\begin{array}{l}\text { Prototype is } \\
\text { used by user } \\
\text { and it is noted } \\
\text { both what has } \\
\text { been worked } \\
\text { out and not }\end{array}$ & $\begin{array}{l}\text { Prototype is used } \\
\text { by user and it is } \\
\text { noted both what } \\
\text { has been worked } \\
\text { out and not, } \\
\text { with the points } \\
\text { need to be } \\
\text { improved }\end{array}$ & $\begin{array}{l}\text { Prototype is used by } \\
\text { user and it is noted } \\
\text { both what has been } \\
\text { worked out and not, } \\
\text { with the points need to } \\
\text { be improved and what } \\
\text { have surprised design } \\
\text { team }\end{array}$ & \\
\hline & & & & Total & \\
\hline
\end{tabular}




\section{Annex 5. Observation Form}

\begin{tabular}{|c|c|c|c|c|c|c|c|c|c|c|c|c|c|c|c|c|c|c|c|c|c|c|}
\hline 憵悬 & \multicolumn{4}{|c|}{ EMPATHY } & \multicolumn{5}{|c|}{$\begin{array}{l}\text { DEFINING/ POINT OF } \\
\text { VIEW }\end{array}$} & \multicolumn{5}{|c|}{ BRAINSTORMING } & \multicolumn{4}{|c|}{ PROTOTYPING } & \multicolumn{4}{|c|}{ TESTING } \\
\hline Level & 1 & 2 & 3 & 4 & 1 & 2 & & 3 & 4 & 1 & 2 & & & 4 & 1 & 2 & 3 & 4 & 1 & 2 & 3 & 4 \\
\hline 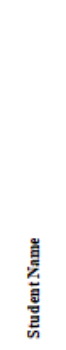 & 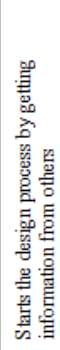 & 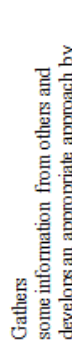 & 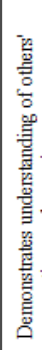 & 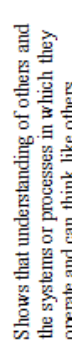 & 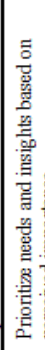 & 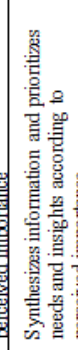 & & 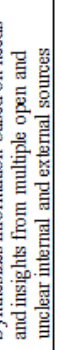 & 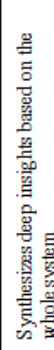 & 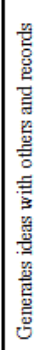 & 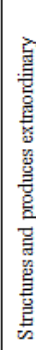 & 递 & & : & 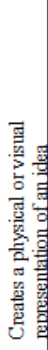 & 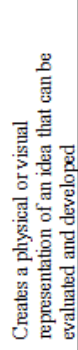 & 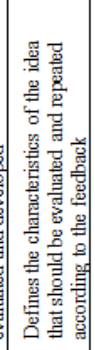 & 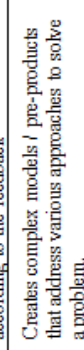 & 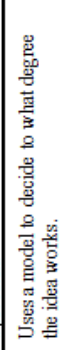 & 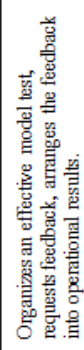 & 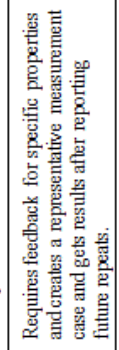 & 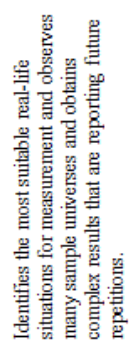 \\
\hline $\begin{array}{l}\text { Student } \\
1\end{array}$ & & & & & & & & & & & & & & & & & & & & & & \\
\hline $\begin{array}{l}S_{2}^{S t u d e n t} \\
2\end{array}$ & & & & & & & & & & & & & & & & & & & & & & \\
\hline $\begin{array}{l}3^{S t u d e n t} \\
\end{array}$ & & & & & & & & & & & & & & & & & & & & & & \\
\hline$\cdots$ & & & & & & & & & & & & & & & & & & & & & & \\
\hline Total & & & & & & & & & & & & & & & & & & & & & & \\
\hline
\end{tabular}

